Article

\title{
Species-Specific Antioxidant Power and Bioactive Properties of the Extracts Obtained from Wild Mediterranean Calendula Spp. (Asteraceae)
}

\author{
Concetta Maria Messina ${ }^{1, *(D)}$, Angelo Troia ${ }^{2}$, Rosaria Arena ${ }^{1}\left(\right.$, Simona Manuguerra ${ }^{1}(\mathbb{D}$, \\ Theodora Ioannou ${ }^{3}$, Eleonora Curcuraci ${ }^{1}$, Giuseppe Renda ${ }^{1}$, Claire Hellio ${ }^{4}$ and \\ Andrea Santulli ${ }^{1}$ (D) \\ 1 Laboratorio di Biochimica Marina ed Ecotossicologia, Dipartimento di Scienze della terra e del Mare DiSTeM, \\ Università degli Studi di Palermo, Via G. Barlotta 4, 91100 Trapani, Italy; rosaria.arena@unipa.it (R.A.); \\ simona.manuguerra@unipa.it (S.M.); eleonora.curcuraci@unipa.it (E.C.); giuseppe.renda02@unipa.it (G.R.); \\ andrea.santulli@unipa.it (A.S.) \\ 2 Dipartimento di Scienze e Tecnologie Biologiche, Chimiche e Farmaceutiche (STEBICEF), \\ Università degli Studi di Palermo, 90123 Palermo, Italy; angelo.troia@unipa.it \\ 3 Department of chemistry, Faculty of Science, Aristotle University of Thessaloniki, 54124 Thessaloniki, \\ Greece; theodora_yoannou@yahoo.gr \\ 4 Univ Brest, CNRS, IRD, Ifremer, LEMAR, Institut Universitaire Européen de la Mer, F-29280 Plouzané, \\ France; Claire.hellio@univ-brest.fr \\ * Correspondence: concetta.messina@unipa.it
}

Received: 1 October 2019; Accepted: 25 October 2019; Published: 31 October 2019

check for updates

\begin{abstract}
In this study we focused on four taxa of the genus Calendula (C. maritima, C. suffruticosa subsp. fulgida, C. arvensis, and the hybrid between the first two ones), collected in Mediterranean area (Sicily). Six extracts for each species were obtained using solvents with increasing polarity (hexane, ethanol $80 \%$, acetone $70 \%$, and water) and through extraction by supercritical fluids (SFE). It has been observed that the solvent with the highest extraction efficiency was ethanol $80 \%$ for all species. However, SFE extracts showed high antioxidant activity comparable to the ethanol $80 \%$ extract (polyphenol, DPPH, and reducing power method). These findings were confirmed by in vitro analysis (MTT assay) where it was observed that the tested concentration $(24 \mu \mathrm{g} / \mathrm{mL})$, obtained from ethanol $80 \%$ and SFE extracts, showed a protective effect comparable to that induced by a synthetic antioxidant. Extraction with SFE ensured a great selectivity by avoiding the use of toxic organic solvents and thus consisted of a promising technique for sustainable production of Calendula extracts.
\end{abstract}

Keywords: calendula species; marigold; supercritical fluid extraction; bioactivity; antioxidants; polyphenols

\section{Introduction}

The genus Calendula (Asteraceae) includes several species (known commonly as "Marigolds") that have been reported since antiquity for their therapeutic properties and/or use as ingredients in food preparation. There is no agreement on the number of species within the genus, owing to the high number of taxa differently considered by different authors, but recently, this number has been proposed to be 15 [1], with several infraspecific taxa.

The most studied species within the genus is Calendula officinalis L., an ornamental and medicinal plant, of unknown origin, usually cultivated but sometimes escaped and/or naturalized in several regions [1]. C. officinalis extract and pure compounds isolated from different organs possess multiple pharmacological activity, including anti-inflammatory, antioedematous, antioxidant, immunostimulant, lymphocyte and wound healing, hepatoprotective, antimicrobial, antibacterial and antifungal, 
anti-HIV, spasmolytic and spasmogenic, genotoxic and antigenotoxic, antiviral, and anticancer [2-4]. These properties are due to the presence of secondary metabolites, such as carotenoids, polyphenols, and flavonoids [3-5].

In particular, polyphenols represent a family of organic molecules widely distributed in the plant kingdom. Their chemical structures are characterized by the presence of different phenolic groups, which can be associated with more or less complex groups of chemicals, generally of high molecular weight. The growing interest in polyphenols comes from their antioxidant potential, which is involved in health benefits such as inflammation and cancer prevention [6,7], cardiovascular dysregulation, and neurodegenerative diseases. Due the mechanisms involved in the production, recently, this class was also recognized as a useful biomarker to reveal the resistance of plants and algae to environmental conditions $[8,9]$.

Despite a long tradition of use of some species, the genus has not been explored properly, and few species (apart from C. officinalis) have been studied for their phytochemistry and ethnopharmacological aspects $[3,10]$.

In our work, we focused on the leaves of untapped wild Mediterranean species, potentially useful as source of important molecules for potential biotechnological applications. Thus, three species and one hybrid were investigated: Calendula maritima Guss. (CM), Calendula suffruticosa subsp. fulgida (Raf.) Guadagno (CF), Calendula arvensis (Vaill.) L. (CA) and hybrid (CI) between the CM and CF. CM, perennial, is endemic to Western Sicily, where it grows along the coast lines; it is one of the most endangered species on a global scale [11]. The risk of extinction is due to direct or indirect human actions [11-13]. CF, perennial, can be found throughout Sicily, Malta, in parts of southern mainland Italy and Tuscany, and also in Morocco [14]. Present in various habitats (including disturbed areas such as fallow fields and road cuts), it is not endangered, but it is supposed [14] to threaten the populations of CM through the formation of hybrids. CA, annual, native all around the Mediterranean area from Macaronesia to SW Asia (and introduced in other parts of the globe such as Australia and California) [1], it grows in fields, vineyards, and waste grounds.

This species has also many uses since ancient times: CA and CM had high antioxidant activity, whereas only few data are available regarding antioxidant potency and chemical composition of CF and CI [15]. In any case, regardless of the species considered, the antioxidant activity could be responsible for the effects reported, both from the phytotherapeutic traditional usages and the scarce available literature about the bioactivity of the plants of this family (anti-inflammatory, healing, antispasmodic) [16-21].

The taxa here investigated occur in different habitats: the rare endemic CM is linked to peculiar coastal areas, the more opportunistic $\mathrm{CF}$ is able to colonize several different environments, the hybrid $\mathrm{CI}$ testifies to special evolutionary events when $\mathrm{CM}$ and CF come into contact, and the widespread CA is common in cultivated or disturbed areas. Ecological characteristics of a species can often explain its different properties in terms of the production of bioactive molecules as a defence strategy against specific, changing, or extreme environmental conditions [9]. This is why we wanted to draw attention to antioxidants which are some of the key molecules involved in the ability of animals and plants to adapt to environmental and climate change. Our aim was to verify whether, in the different Calendula species analysed, collected in different areas and at the same time of the year, there was a different ability to produce antioxidant compounds. Nowadays, the search for antioxidants is at the forefront of research in science not only for industrial application related to health and food [22-25] but also focusing on organisms defences strategies toward environmental changes [9]. For example, antioxidants represent a promising solution in microbiology fields in order to fight against bacterial resistance and appearance of new pathogen microorganisms and diseases [26,27].

The major interest of the potential application of antioxidants, not only in the pharmaceutical industry but also as food additives, lies in their ability both to bind free radicals produced in the human body and to their bactericidal or fungicidal action against certain pathogens. Oxygen is an abundant element in nature and necessary for the preservation of life, but it can be fatal to human 
health, depending on the conditions and form in which it is found in cells. During respiration, it is possible that oxygen free radicals, called ROS (reactive oxygen species), produce free radicals which, if they do not deactivate from the endogenous mechanism, can cause significant damage to organisms and gradually lead to their destruction [28,29].

Antioxidants are secondary metabolites, the majority of which belong to the class of phenolic compounds, then terpenes. These substances are produced under specific conditions, depending on the environment in which the organisms develop. Secondary metabolites are involved in the plant defence mechanisms, conferring resistance to microorganisms and insects, and other studies link antioxidant production to strategies adopted by organisms to adapt to changing environmental conditions and climate change [30]. In addition, their presence is important to protect against harmful UV rays. In fact, recent studies have shown that $C$. officinalis extract acts to prevent oxidative stress induced by UV radiation on the skin [31].

Traditional extraction methods used to obtain bioactive compounds depend on the polarity of the solvent, which qualitatively and quantitatively determines the antioxidant compounds extracted $[9,32]$. Supercritical fluid extraction (SFE) is an extraction method that offers greater selectivity, shorter extraction times, and does not use toxic organic solvents [33] as compared to traditional extraction methods [34]. The aim of this research was to assess the antioxidant power of different Calendula species collected in Sicily, extracted using different solvents and by SFE, and to evaluate the bioactive properties exerted in vitro, for potential biotechnological applications.

\section{Materials and Methods}

\subsection{Materials}

Potassium ferricyanide and trichloroacetic acid were bought from Carlo Erba reagents (Milano, Italy). Hexane, ethanol, acetone, gallic acid, Folin and Ciocalteu's phenol reagent, iron (III) chloride $\left(\mathrm{FeCl}_{3}\right)$, 1,1-diphenyl-2-picryhydrazyl (DPPH), human skin fibroblasts (Sigma ${ }^{\circledR} \mathrm{HS68}$ ), Dulbecco's Modified Eagle's Medium (DMEM), foetal bovine serum, glutamine and penicillin-streptomycin were obtained from Merck KGaA (Darmstadt, Germany).

\subsection{Samples Collection, Processing, and Preparation of Plant Extract}

Three of the taxa here analysed (CM, CF, CI) were collected along the coast North of Trapani in Sicily, during the flowering period (March-September) in 2018. CA was collected near Caltanissetta province, in Sicily, in the same period (Spring 2018). All plants were growing wild in natural populations and were collected in three replicates. The plant specimens that were preserved as herbarium specimens were identified using the standard references for this purpose [14]. After harvesting, the plants were taken to the laboratory where they were processed in order to separate leaf. The leaves were dried for $48 \mathrm{~h}$ at $40^{\circ} \mathrm{C}$, grounded into fine powders, and extracted [9]. Leaved extracts were performed by solvents and by supercritical fluids extraction (SFE) as explained below.

\subsubsection{Extraction with Solvents}

The polarity of the solvent influences the extraction yield and the antioxidant activity of the extracts. The use of different solvents is due to the nature of the polyphenols present in the samples. The polyphenols have a different solubility, which is due to the presence of hydroxyl groups, the molecular size, and the length of the hydrocarbons [32].

For extraction of compounds, solvents with different polarity, hexane, ethanol $80 \%$, acetone $70 \%$, and water were used $[9,35]$.

For each plant, one gram of dried leaves were transferred into a flask containing $10 \mathrm{~mL}$ of the solvents (hexane, ethanol $80 \%$, acetone $70 \%$, and water) used for the extraction [9].The materials were then homogenized during five minutes at $4{ }^{\circ} \mathrm{C}$, using an Ultra-Turrax (IKA, Werke Staufen, Germany) at 24,000 rpm according to a consolidated protocol [36-38]. In order to calculate the extraction yield 
$(\mathrm{w} / \mathrm{w})$, an aliquot of each extract (hexane, ethanol $80 \%$, and acetone $70 \%$ ) was evaporated in a rotary vacuum evaporator and weighed as described by Manuguerra et al. [39]. The following Equation (1) was used:

$$
\text { Yield of extract }(\%)=\text { weight of extract/weight of sample } \times 100
$$

The matrices extracted with water were centrifuged at $500 \mathrm{~g}$ for $10 \mathrm{~min}$ at $4{ }^{\circ} \mathrm{C}$ for 3 times. They were then filtered (Whatman ${ }^{\circledR}$ qualitative filter paper, Grade $93-10 \mu \mathrm{m}$, Merck KGaA Darmstadt, Germany) and freeze-dried [9].

\subsubsection{Extraction with Supercritical Fluid Extraction (SFE)}

The supercritical technology was applied for the extraction of phenolic compounds with antioxidant activity from four Calendula species, using supercritical (SC)- $\mathrm{CO}_{2}$ and $\mathrm{SC}-\mathrm{CO}_{2}$ with co-solvents. This alternative method was compared to traditional extraction methods with different organic solvent, in terms of yield and product quality evaluated by the antioxidant activity of the extracts. It has been reported that $\mathrm{SFE}$ with $\mathrm{CO}_{2} / \mathrm{EtOH}$ was the best method used, combining extraction yield and product quality (antioxidant activity and total phenolic compounds) [34].

A supercritical extraction unit (SFE System model HELIX, Applied Separations Allentown, PA, USA) equipped with a $\mathrm{CO}_{2}$ pump unit and a steel vessel with a volume of $50 \mathrm{~mL}$ was used. Extraction was conducted on the four species studied. 1:2 (w/w) of plant dried powder $(5 \mathrm{~g})$, and hydroscopic dispersing agent (Applied Separations, Allentown, PA, USA) was placed in the extraction vessel sandwiched with defatted glass wool forming a fixed bed in the vessel. For each species, the unit was pressurized and the sample was kept in contact with $\mathrm{SC}-\mathrm{CO}_{2}$ (SFE) or SC-CO $\mathrm{CO}_{2}$ with co-solvent (ethanol 95\%) (SFE CS) at pre-established conditions of temperature $\left(50^{\circ} \mathrm{C}\right)$ and pressure $(300 \mathrm{bar})$ for $30 \mathrm{~min}$ in static mode [34]. These parameters are more efficient in terms of yield, as demonstrated by Castro-Vargas et al. [34]. Dynamic extraction was carried out with a $\mathrm{CO}_{2}$ flow of $5 \mathrm{lpm}$ (liter per minute) and a co-solvent flow of $0.25 \mathrm{~mL} / \mathrm{min}$ for one hour. The co-solvent was pumped through the sample using an HPLC pump (Knauer Smartline pump 1050, Berlin, Germany). Extract was obtained in the sample vial collector and stored at $-20^{\circ} \mathrm{C}$.

\subsection{Characterization of the Antioxidant Power}

\subsubsection{Total Polyphenols Contents}

Total phenolics were analysed using Folin-Ciocalteu's assay. Gallic acid was used as standard for calibration $(5-500 \mathrm{mg} / \mathrm{mL}$ ) and results were expressed as $\mathrm{mg}$ of gallic acid equivalents (GAE) per $\mathrm{g}$ of the Calendula dw $[9,39,40]$. Each sample was analysed in triplicate.

\subsubsection{DPPH Radical Scavenging Activity}

The DPPH (1,1-diphenyl-2-picryhydrazyl) radical scavenging activity of different extracts was assessed using a slightly modified version of the method described by Bernatoniene et al. (2011): $400 \mu \mathrm{L}$ of various concentrations $(1-10 \mathrm{mg} / \mathrm{mL})$ of the ethanolic extracts was replenished up to $2.0 \mathrm{~mL}$ with $0.1 \mathrm{mM}$ DPPH radical solution in ethanol [5].

After $30 \mathrm{~min}$ of incubation the absorbance was read against the blank at $517 \mathrm{~nm}$. Gallic acid was employed as the reference. Inhibition of DPPH free radical was calculated using the following formula (2) and was expressed as percentage of inhibition (I\%):

$$
\mathrm{I} \%=1-\left(\mathrm{A}_{\text {sample }} / \mathrm{A}_{\text {blank }}\right) \times 100
$$

where $\mathrm{A}_{\text {blank }}$ is the absorbance of the control reaction, and $\mathrm{A}_{\text {sample }}$ is the absorbance of the test sample. The inhibition values were calculated for extracts at concentrations from 1 to $10 \mathrm{mg} / \mathrm{mL}$, and the slope of the linear portion of each graph was used to calculate IC 50\% which is the concentration when $50 \%$ of the antioxidant is reduced [41]. 


\subsubsection{Reducing Power}

The potency of extracts to reduce iron (III) was determined according to the method of Oyaizu (1986). Sample solutions at different concentrations (from 0.1 to $10 \mathrm{mg} / \mathrm{mL})(300 \mu \mathrm{L}$ ) were mixed with phosphate buffer $\left(300 \mu \mathrm{L}, 0.2 \mathrm{M}, \mathrm{pH}\right.$ 6.6) and potassium ferricyanide $\left[\mathrm{K}_{3} \mathrm{Fe}(\mathrm{CN})_{6}\right](300 \mu \mathrm{L}, 1 \%)$; the mixture was incubated at $50{ }^{\circ} \mathrm{C}$ for $20 \mathrm{~min} .300 \mu \mathrm{L}$ of trichloroacetic acid $(10 \%)$ was added to the mixture, prior to centrifugation at $3000 \mathrm{rpm}$ for $10 \mathrm{~min}$ at $4{ }^{\circ} \mathrm{C}$. The upper layer of solution $(300 \mu \mathrm{L})$ was mixed with distilled water $(300 \mu \mathrm{L})$ and $\mathrm{FeC}_{3}(600 \mu \mathrm{L}, 0.1 \%)$, and the absorbance was measured at $700 \mathrm{~nm}$ against gallic acid as standard. Increased absorbance of the reaction mixture indicated increased reducing power. $\mathrm{EC}_{50}$ value $\left(\mathrm{mg} / \mathrm{mL}^{-1}\right)$ is the effective concentration of the extract at which the absorbance was 0.5 , and it was obtained from linear regression analysis $[39,42]$.

\subsection{Evaluation of Bioactive Properties in Vitro}

Protective Effect of Calendula Spp. Extracts in Fibroblast Cell Line HS-68 Exposed to Oxidative Stress

Human skin fibroblasts (Sigma ${ }^{\circledR}$ HS68) were cultured as monolayers in Dulbecco's Modified Eagle's Medium (DMEM) supplemented with 10\% foetal bovine serum, $2 \mathrm{mM}$ glutamine, and $100 \mu \mathrm{g} / \mathrm{mL}$ penicillin-streptomycin and incubated in a humidified atmosphere at $5 \% \mathrm{CO}_{2}, 95 \%$ air, and $37^{\circ} \mathrm{C}$. All cell culture methods were performed under sterile conditions using a grade II flow hood. Confluent cells were trypsinized and seeded in a 96-well plate at a concentration of $7 \times 10^{3}$ cells/well and incubated for $24 \mathrm{~h}$. Later, cells were treated with different Calendula species (CM, CF, CI, and CA) extracts. The extracts were dissolved in ethanol and utilized at varying concentration ranging from $2.4-24 \mu \mathrm{g} / \mathrm{mL}$ in the medium, with a final solvent concentration of $0.1 \%(\mathrm{v} / \mathrm{v})$. Cells were exposed for $24 \mathrm{~h}$, to individuate the adequate concentration of compounds that does not determine significant toxicity, useful to realize experiments of induction of oxidative stress.

The effects associated with the treatment of cells with ethanol alone, on HS-68 cells, were previously assessed as routinely procedure in the lab, and it was demonstrated that the selected percentage of the vehicle did not exert any effects on cell vitality $[39,43]$.

After the individuation of the range of concentration that does not induce significant cell mortality, cells were again seeded on 96 well plate; a set of samples represented the control (Co) and were maintained only with culture medium; a subset of samples were treated with concentration $24 \mu \mathrm{g} / \mathrm{mL}$ of Calendula; additional wells were treated with the antioxidant NAC, that inhibits oxidative stress formation $[39,43,44]$; another set of samples were not treated with Calendula extracts, but only with the inducer of oxidative stress (HP). After $24 \mathrm{~h}$, all samples, except the control, were exposed to the chemical promoter of oxidative stress, hydrogen peroxide $(50 \mu \mathrm{M})$ according to a previous standardized protocol $[39,43,44]$, and left to incubate at $37^{\circ} \mathrm{C}$ for $2 \mathrm{~h}$. The vitality of cells was measured using the MTT method according to Mosmann [45]. Results were expressed as percentage of viable cells in respect to the control. Each experiment of viability was carried on in triplicate.

\subsection{Statistical Analysis}

Statistical differences were evaluated for each parameter with analysis of variance (ANOVA). The differences among the mean values were assessed using the Student-Newman-Keuls or Games Howell test, depending on the homogeneity of the variables test. The homogeneity of variance was confirmed by the Levene test. The significance level was $95 \%$ in all cases $(p<0.05)$. All the data were analysed by the computer application SPSS for Windows ${ }^{\circledR}$ (version 20.0, SPSS Inc., Chicago, IL, USA).

\section{Results and Discussion}

\subsection{Extraction and Evaluation of Antioxidant Power}

Only scarce information is known about the antioxidant capacity and other therapeutic properties of the species analysed in this work, as most of the currently published research concerns C. officinalis; 
the only species for which some data are available is the widespread CA $[10,46]$, whereas the results here presented for $\mathrm{CM}$ and $\mathrm{CF}$ are the first available for those taxa, as far as we know. Including CA (for which other data are available), the (up to now) un-investigated $\mathrm{CM}$ and $\mathrm{CF}$, and their hybrid $\mathrm{CI}$ makes it possible a useful comparison also with previously published data. Figure 1 shows the yield of extraction obtained from the matrix of dried leaves of different species of Calendula, comparing different solvents. It has been observed that the solvent with the highest extraction efficiency is ethanol $80 \%$ for all species with values ranging from $21.27 \pm 0.19(\mathrm{~g} / 100 \mathrm{~g})(\mathrm{CM})$ to $28.16 \pm 3.24$ (g/100 g) (CI). Significantly lower yields were obtained with SFE, SFE with co-solvent (SFE CS) and with n-Hexane. The extraction yield and antioxidant activity of plant extracts strongly depend on the polarity of the solvent, which determines both qualitatively and quantitatively the antioxidant compounds extracted $[9,32]$.

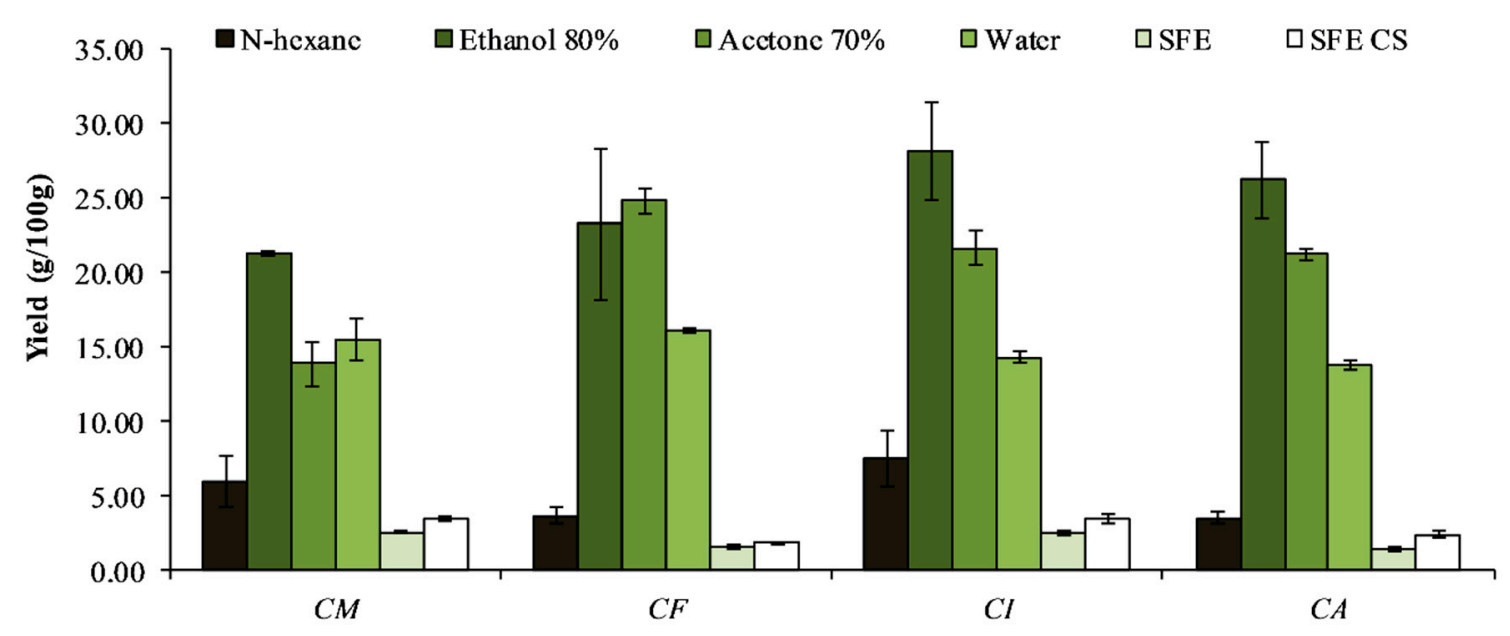

Figure 1. Yield $(\mathrm{g} / 100 \mathrm{~g})$ determined on the matrix of dried leaves of four Calendula taxa (CM: C. maritima; CF: C. fulgida; CI: C. hybrid (maritima $\times$ fulgida); CA: C. arvensis), extracted with different solvents (Results of the statistical analysis are shown in Supplementary Table S1).

In the literature, it has been observed that the highest yields are usually obtained with ethanol, methanol, and their mixtures with water [32]; similar results have been observed on C. officinalis, where the methanolic and ethanolic extracts for the antioxidant analysis have shown the highest efficiency for the selective isolation of these compounds from this species [21,46,47]. Ercetin et al. [48] reported similar efficiency for the extracts of leaves and flower for CA.

The most commonly used solvents are water and ethanol due to their low toxicity and high extraction efficiency. The main disadvantage of aqueous extraction is the low yield of low-polarity antioxidants or fat-soluble antioxidants such as carotenoids [32]. In our work, it has been observed that the yield of the aqueous extract has been significantly lower than the hydroalcoholic extract (Figure 1); for this reason, it is appropriate and advantageous to modulate the polarity of the solvent using ethanol/water mixtures in different ratios [32].

Even if the yield with SFE was lower than the yield obtained with other solvents, the use of this technique allows to obtain of a solvent-free extract, since $\mathrm{CO}_{2}$ is used as a supercritical fluid $[9,49]$. $\mathrm{CO}_{2}$ is a gas at room temperature, so once the extraction is completed and the system decompressed, a substantial elimination of $\mathrm{CO}_{2}$ is achieved without residues, yielding a solvent-free extract $[33,50]$.

\subsubsection{Total Phenolic Content}

The experimental results, presented in Figure 2, showed that the highest content of phenolic compounds was recorded in the ethanol $80 \%$ leave extracts of CA and CF. This outcome was expected as ethanol is a very efficient solvent for antioxidant extraction; in fact, there is a certain correlation 
between polarity and polyphenolics extraction yield. Instead, for extracts obtained with SFE, a lower content of polyphenols related to the yield is observed.

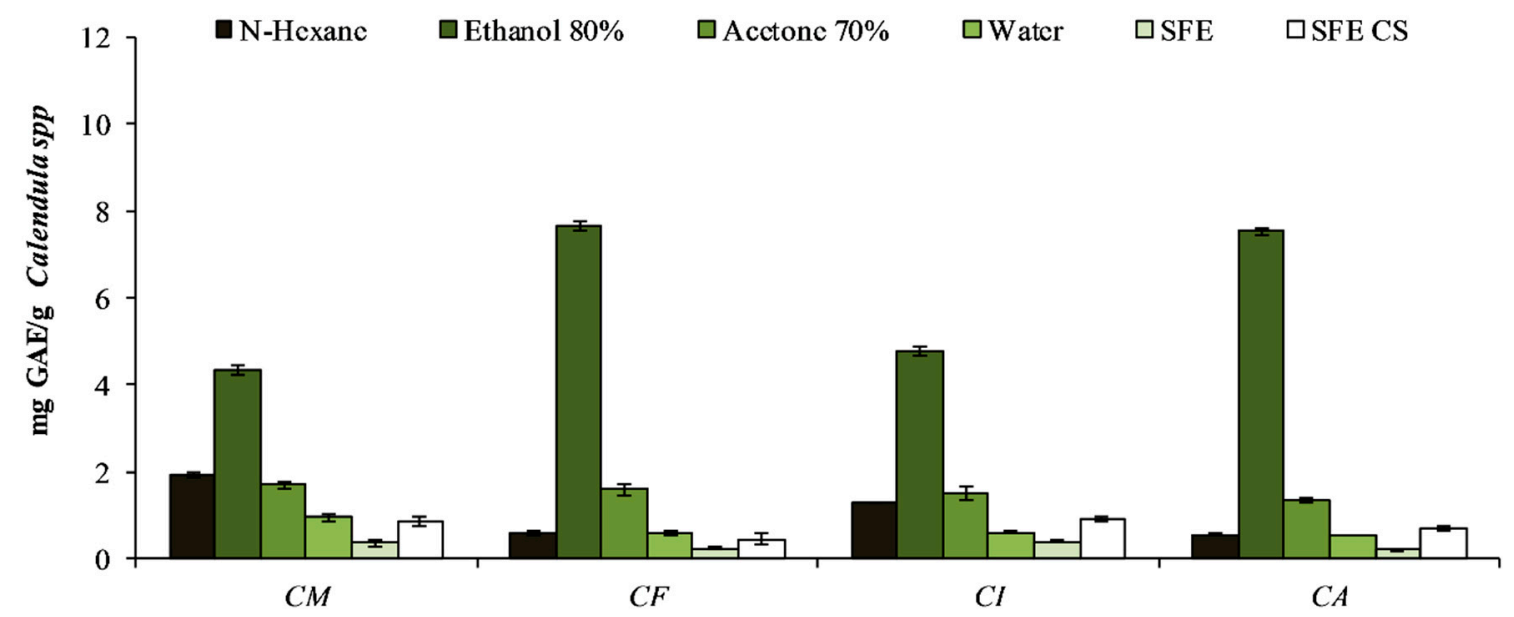

Figure 2. Total phenolic content (mg GAE/g) in extracts obtained from dried leaves of four Calendula taxa (CM: C. maritima; CF: C. fulgida; CI: C. hybrid (maritima $\times$ fulgida); CA: C. arvensis), with different solvents (Results of the statistical analysis are shown in Supplementary Table S2).

As expected, the hybrid CI shows intermediate values between the two parents, $\mathrm{CM}$ and CF.

\subsubsection{1-Diphenyl-2-picrylhydrazyl (DPPH) Assay}

DPPH radical scavenging activity is one of the available tests used for estimating the antioxidant activity of natural products [42,51]. The results (Figure 3) showed that ethanol $80 \%$ extracts have the highest antioxidant activity. Among the different species analysed, CF and CA are the two species that show the highest antioxidant activity displaying the lowest values of $\mathrm{IC}_{50}$, followed by $\mathrm{CI}$ and $\mathrm{CM}$.

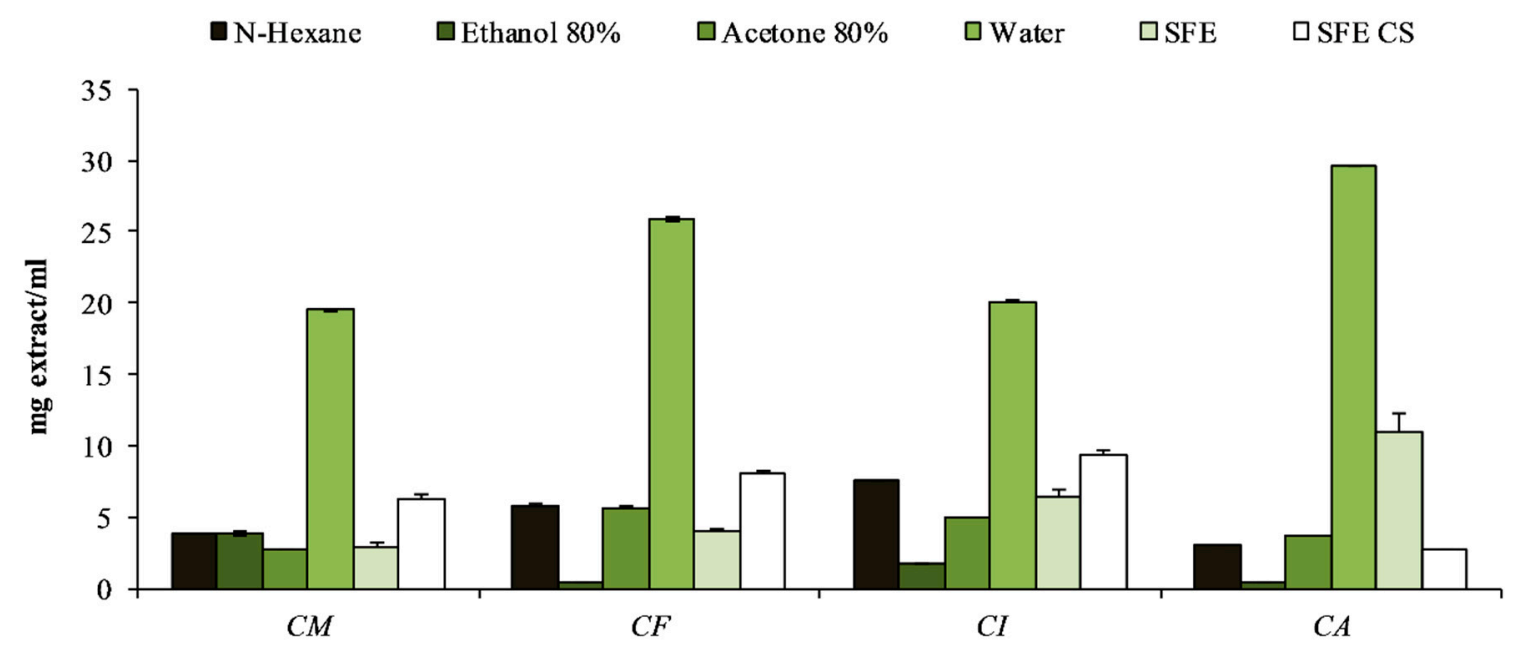

Figure 3. DPPH radical scavenging activity (IC 50, $\mathrm{mg} / \mathrm{mL}$ ) determined in extracts obtained from dried leaves of different Calendula species (CM: C. maritima; CF: C. fulgida; CI: C. hybrid (maritima $\times$ fulgida); CA: C. arvensis), with different solvents (Results of the statistical analysis are shown in Supplementary Table S3).

N-hexane, which is the least polar solvent, has a low extraction yield and moderate activity as a percentage of DPPH inhibition, while ethanol $80 \%$, which was slightly more polar, was the best extraction solvent. In this case the more polar solvents, such as water, did not demonstrate high antioxidant activity. 
Extracts obtained with SFE (Figure 2) showed high antioxidant activity, in particular CM extracted with SFE showed better antioxidant activity with $\mathrm{IC}_{50}$ value $(2.84 \pm 0.37)$ significantly lower than the $\mathrm{IC}_{50}$ of the ethanol $80 \%$ extract $(3.81 \pm 0.16)$.

\subsubsection{Reducing Power}

The reducing power supports the antioxidant activity, and it is linked to the presence of reducing agents that, through the donation of a hydrogen atom to free radicals, convert them into stable compounds, breaking the oxidizing chain reaction [51]. In the reducing power assay, the results are expressed as $\mathrm{EC}_{50} / \mathrm{mg}$ extract, where $\mathrm{EC}_{50}$ value $\left(\mathrm{mg} \mathrm{mL}^{-1}\right)$ is the effective concentration of the extract at which the absorbance was 0.5. The results presented in Figure 4 corroborate the previous results; in fact, a greater reducing activity is observed for the samples extracted with ethanol $80 \%$ and, among these $\mathrm{CA}$ and $\mathrm{CF}$, are the two with the best performance. The SFE extracts showed a high reducing activity, in particular for the species $\mathrm{CA}$ and $\mathrm{CF}$ the values of $\mathrm{EC}_{50}$ are similar to the ethanol $80 \%$ extracts.

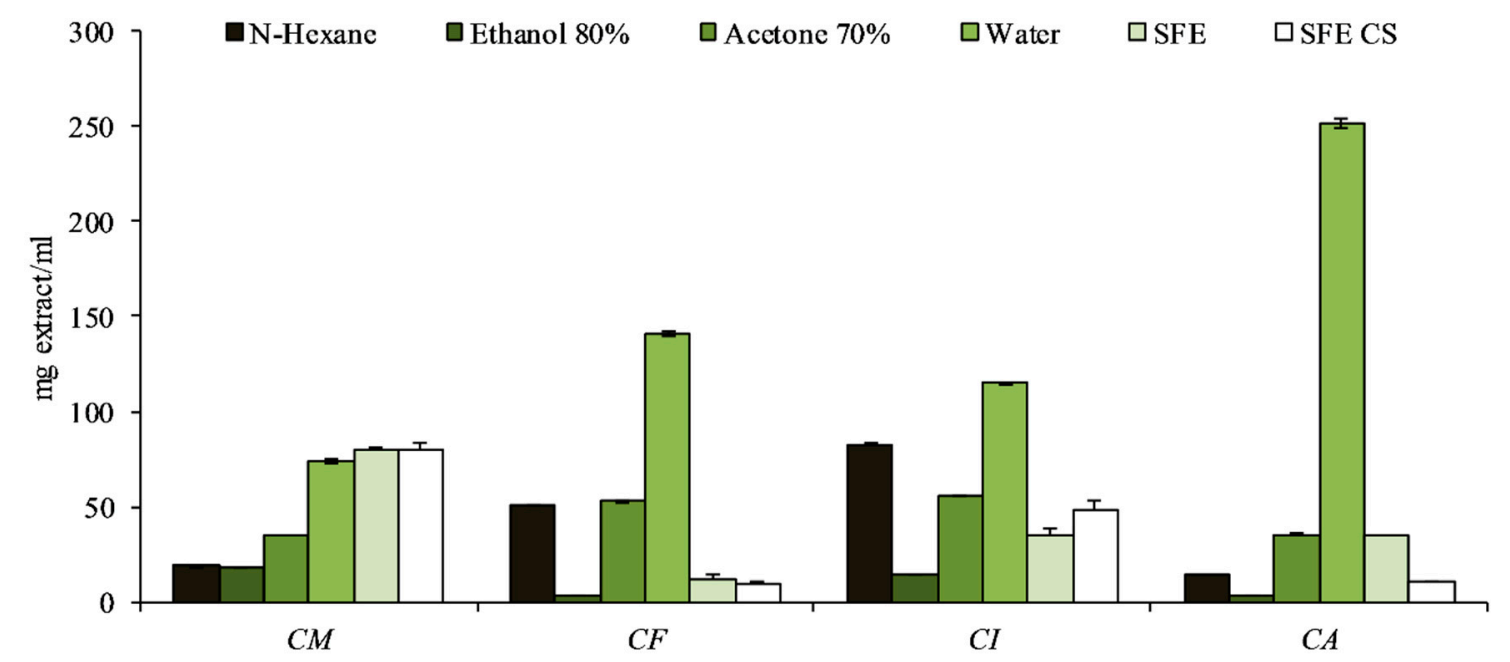

Figure 4. Reducing power $\left(\mathrm{EC}_{50}, \mathrm{mg} / \mathrm{mL}\right)$ determined in extracts obtained from dried leaves of different Calendula species (CM: C. maritima; CF: C. fulgida; CI: C. hybrid (maritima $\times$ fulgida); CA: C. arvensis), with different solvents (Results of the statistical analysis are shown in Supplementary Table S4).

\subsection{Protective Effect of Calendula Spp. Extracts in Fibroblast Cell Line HS-68 Exposed to Oxidative Stress}

After the preliminary evaluation of the antioxidant activity, the extracts made in ethanol $80 \%$, SFE, and SFE CS were selected for the test vitro. The viability of human skin fibroblasts cells (HS68) was determined in order to evaluate the cytotoxicity of extract of Calendula. Figure 5 shows the response of the fibroblast cells to increasing concentrations of Calendula extract with ethanol $80 \%$, SFE, and SFE CS (Figure 5). Results are expressed as a percentage of vitality cells in respect to the control (cells with no treatment). Concentrations between $2.4-24 \mu \mathrm{g} / \mathrm{mL}$ does not exert a significant effect on the viability after $24 \mathrm{~h}$ of treatment compared with control (Co) (Figure 5). These results support the observations of Matysik et al. [52], who showed that Calendula extract in small concentrations can stimulate the proliferation of human fibroblasts.

The experiment of induction of oxidative stress was carried with higher concentration of Calendula for all species, which does not induce significant toxicity. Figure 5 shows that the exposure of cells to a well-known concentration of Hydrogen Peroxide (HP) able to induce toxicity in this cell line $[39,43,44]$ determined a significant decrease of vitality, calculated by MTT test $(p<0.05)$.

At $24 \mathrm{~h}$ post treatment, the concentration $24 \mu \mathrm{g} / \mathrm{mL}$ obtained from of ethanol $80 \%$, SFE, and SFE CS extracts of Calendula (CF, CI, and CA) shows a protective effect comparable to the effect induced by the synthetic antioxidant $\mathrm{N}$-acetilcysteine (NAC) (Figure 6). 


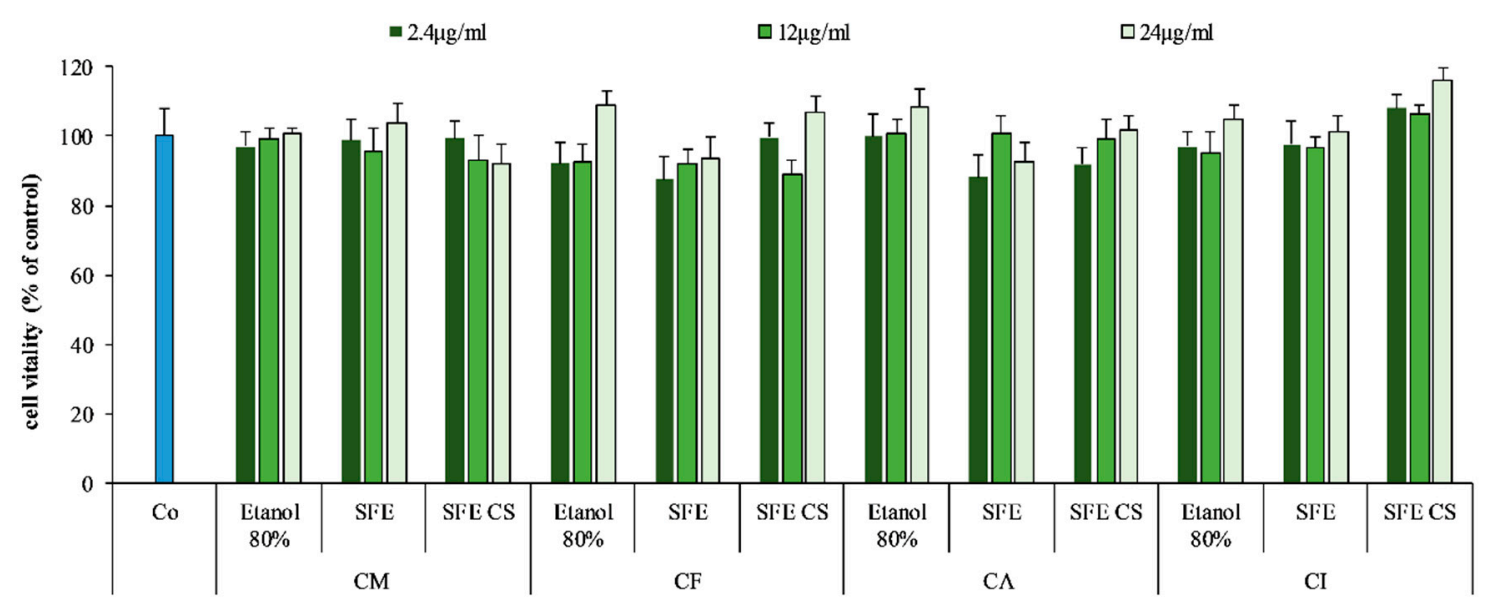

Figure 5. Percentage of vitality of HS68 fibroblast cells, determined by MTT (each data is presented as mean \pm SD; $\mathrm{n}=12$ ). Cells treated with different extracts of Calendula (ethanol $80 \%$, SFE and SFE CS) for $24 \mathrm{~h}$ to concentrations $2.4,12$, and $24 \mu \mathrm{g} / \mathrm{mL}(0.1 \%<$ ethanol). Co = control (no treatment); CM: C. maritima; CF: C. suffruticosa subsp. fulgida; CI: C. hybrid (maritima $\times$ fulgida); CA: C. arvensis.

घEthanol $80 \%$

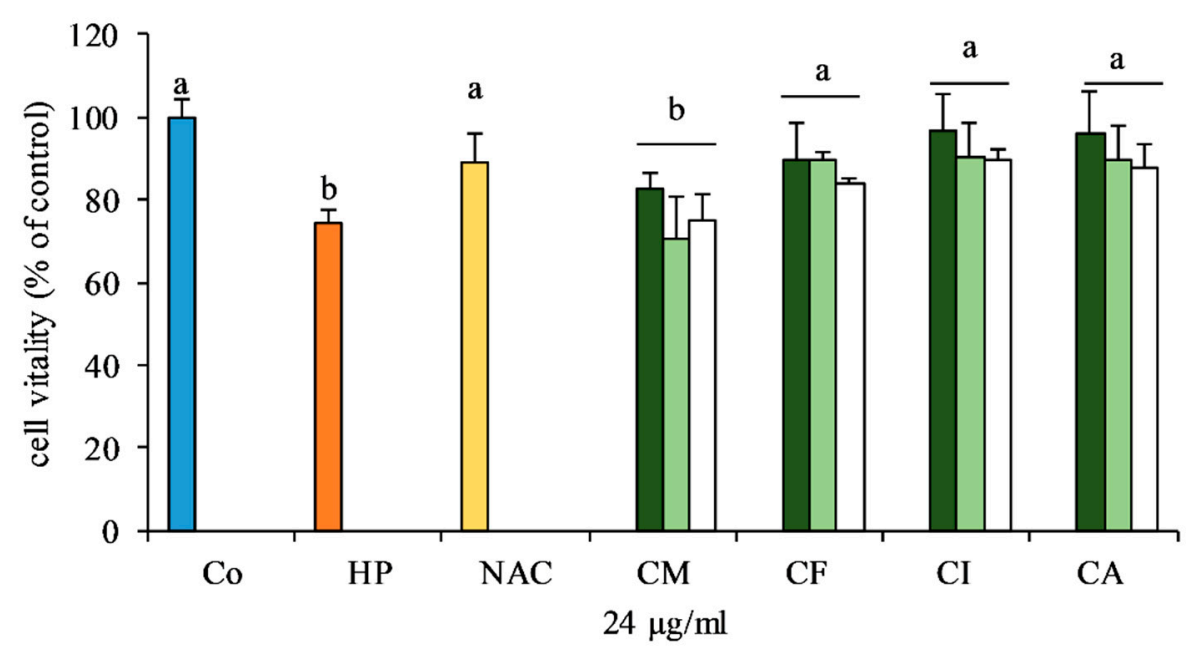

Figure 6. Effect of Calendula extract on fibroblast cells exposed to oxidative stress, induced by $\mathrm{H}_{2} \mathrm{O}_{2}$ $\mathrm{Co}=$ control cells; $\mathrm{HP}=$ cells treated only with $\mathrm{HP}$ hydrogen peroxide, without extracts; NAC = cells pretreated with the synthetic antioxidant NAC and then exposed to HP; $\mathrm{CM}=$ cells pretreated with different extracts of $C$. maritima and then exposed to $\mathrm{HP} ; \mathrm{CF}=$ cells pretreated with different extracts of C. suffruticosa subsp. fulgida and then exposed to HP; CI = cells pretreated with different extracts of C. hybrid (maritima $\times$ fulgida) and then exposed to HP; $\mathrm{CA}=$ cells pretreated with different extracts of C. arvensis and then exposed to HP. Lowercase letters indicate significant differences $(\mathrm{a}, \mathrm{b}, \mathrm{c}: p<0.05)$ according to the analysis of variance (ANOVA).

The results indicate that these extracts $(\mathrm{CF}, \mathrm{CI}$, and $\mathrm{CA})$ exerted a protective effect against oxidative damage, scavenging hydrogen peroxide, hydroxyl radicals, and superoxide anions. The treatment with $\mathrm{H}_{2} \mathrm{O}_{2}$ induces superoxide production on the mitochondria and metal ions such as $\mathrm{Fe}^{2+}$ or $\mathrm{Cu}^{2+}$ reduce $\mathrm{H}_{2} \mathrm{O}_{2}$ to hydroxyl radicals [53].

\section{Conclusions}

The polarity of the solvent influences the extraction yield and antioxidant activity both qualitatively and quantitatively. Studies on horseradish have shown that ethanol/water extracts show a better yield than the aqueous extract [39]. In addition, a study conducted on grape pomace showed that in ethanol 
extracts the concentration values of polyphenols were about twice in respect to those found in water; furthermore, ethanol extracts showed the highest DPPH radical scavenging activity [32].

In our work, it has been observed that the various species of Calendula show a high antioxidant activity due to their content in polyphenols and that the use of hydroalcoholic solvents, such as ethanol $80 \%$, allows to obtain a better yield and a more efficient extraction of polyphenols.

The results of the DPPH test and the reducing power indicated that the hydroalcoholic extract has a greater antioxidant power than the extracts obtained with solvents of different polarities and with SFE, due to the content of polyphenols. Moreover, among the various species analysed, CF and CA are those that show a greater antioxidant activity. The in vitro tests confirm the antioxidant properties and the protective effect of Calendula (CF, CI, and CA) extracts with ethanol $80 \%$.

Although the best yields have been observed with the ethanol $80 \%$ extract, the SFE extract shows antioxidant activity similar to the extract obtained in ethanol $80 \%$, so given its eco-friendly characteristics and absence of use of solvents, it seems to be a promising technique for the sustainable production of Calendula extracts to be directed to local niche productions.

Supplementary Materials: The following are available online at http://www.mdpi.com/2076-3417/9/21/4627/s1, Table S1: Statistical analysis performed on the yield $(\mathrm{g} / 100 \mathrm{~g})$ determined on the matrix of dried leaves of four Calendula taxa (CM: C. maritima; CF: C. fulgida; CI: C. hybrid (maritima $\times$ fulgida); CA: C. arvensis), with different solvents; Table S2: Statistical analysis performed on total phenolic content (mg GAE/g) in extracts obtained from dried leaves of four Calendula taxa (CM: C. maritima; CF: C. fulgida; CI: C. hybrid (maritima $\times$ fulgida); CA: C. arvensis), with different solvents, Table S3: Statistical analysis performed on DPPH radical scavenging activity (IC 50, mg/ml) determined in extracts obtained from dried leaves of different Calendula species (CM: C. maritima; CF: C. fulgida; CI: C. hybrid (maritima fulgida); CA: C. arvensis), with different solvents, Table S4: Statistical analysis performed on reducing power $(\mathrm{EC} 50, \mathrm{mg} / \mathrm{ml})$ determined in extracts obtained from dried leaves of different Calendula species (CM: C. maritima; CF: C. fulgida; CI: C. hybrid (maritima $\times$ fulgida); CA: C. arvensis), with different solvents.

Author Contributions: Conceptualization, C.M.M., A.T. and A.S.; data curation, C.M.M.; formal analysis, R.A., S.M., T.I., E.C. and G.R.; investigation, C.H.; supervision, C.M.M. and A.S.; writing-original draft, R.A., S.M. and T.I.; writing-review and editing, C.M.M., A.T., C.H. and A.S.

Funding: This research received no external funding.

Acknowledgments: Theodora Ioannou (from Aristotle University of Thessaloniki, Greece) was awarded an Erasmus+ grant to complete an internship in the Marine Biochemistry and Ecotoxicology Laboratory of the University of Palermo. This collaboration was established thanks to the internship program of the European Society for Marine Biotechnology (ESMB).

Conflicts of Interest: The authors declare no conflict of interest.

\section{References}

1. Gonçalves, A.C.; Castro, S.; Paiva, J.; Santos, C.; Silveira, P. Taxonomic revision of the genus calendula (Asteraceae) in the Iberian Peninsula and the Balearic Islands. Phytotaxa 2018, 352, 1-91. [CrossRef]

2. Khalid, K.A.; Silva, J.A.T. Biology of Calendula officinalis Linn.: Focus on Pharmacology, Biological Activities and Agronomic Practices. Med. Aromat. Plant Sci. Biotechnol. 2012, 6, 12-27.

3. Chakraborthy, G.S. Antimicrobial activity of the leaf extracts of Calendula officinalis (Linn.). J. Herb. Med. Toxicol. 2008, 2, 65-66.

4. Faustino, M.V.; Pinto, D.C.G.A.; Gonçalves, M.J.; Salgueiro, L.; Silveira, P.; Silva, A.M.S. Calendula L. species polyphenolic profile and in vitro antifungal activity. J. Funct. Foods 2018, 45, 254-267. [CrossRef]

5. Bernatoniene, J.; Masteikova, R.; Davalgiene, J.; Peciura, R.; Gauryliene, R.; Bernatoniene, R.; Majiene, D.; Lazauskas, R.; Civinskiene, G.; Velziene, S.; et al. Topical application of calendula officinalis (L.): Formulation and evaluation of hydrophilic cream with antioxidant activity. J. Med. Plants Res. 2011, 5, 868-877.

6. Laughton, M.J.; Evans, P.J.; Moroney, M.A.; Hoult, J.R.S.; Halliwell, B. Inhibition of mammalian 5-lipoxygenase and cyclo-oxygenase by flavonoids and phenolic dietary additives: Relationship to antioxidant activity and to iron ion-reducing ability. Biochem. Pharmacol. 1991, 42, 1673-1681. [CrossRef]

7. El-Mostafa, K.; El Kharrassi, Y.; Badreddine, A.; Andreoletti, P.; Vamecq, J.; El Kebbaj, M.; Latruffe, N.; Lizard, G.; Nasser, B.; Cherkaoui-Malki, M. Nopal Cactus (Opuntia ficus-indica) as a Source of Bioactive Compounds for Nutrition, Health and Disease. Molecules 2014, 19, 14879-14901. [CrossRef] 
8. Mancuso, F.P.; Messina, C.M.; Santulli, A.; Laudicella, V.A.; Giommi, C.; Sarà, G.; Airoldi, L. Influence of ambient temperature on the photosynthetic activity and phenolic content of the intertidal Cystoseira compressa along the Italian coastline. J. Appl. Phycol. 2019, 1-8. [CrossRef]

9. Messina, C.; Renda, G.; Laudicella, V.; Trepos, R.; Fauchon, M.; Hellio, C.; Santulli, A.; Messina, C.M.; Renda, G.; Laudicella, V.A.; et al. From Ecology to Biotechnology, Study of the Defense Strategies of Algae and Halophytes (from Trapani Saltworks, NW Sicily) with a Focus on Antioxidants and Antimicrobial Properties. Int. J. Mol. Sci. 2019, 20, 881. [CrossRef]

10. Arora, D.; Rani, A.; Sharma, A. A review on phytochemistry and ethnopharmacological aspects of genus Calendula. Pharmacogn. Rev. 2013, 7, 179-187. [CrossRef]

11. Troia, A.; Pasta, S. Calendula maritima. IUCN Red List Threat. Species 2006, 2006, T61618A12524417. [CrossRef]

12. Troia, A. Strategie di gestione delle popolazioni di Calendula maritima Guss. (Asteraceae). Nat. sicil. 2011, 35, 51-63.

13. Pasta, S.; Garfi, G.; Carimi, F.; Marcenò, C. Human disturbance, habitat degradation and niche shift: The case of the endemic Calendula maritima Guss. (W Sicily, Italy). Rend. Lincei 2017, 28. [CrossRef]

14. Plume, O.; Raimondo, F.M.; Troia, A. Hybridization and competition between the endangered sea marigold (Calendula maritima Asteraceae) and a more common congener. Plant Biosyst. 2015, 149, 68-77. [CrossRef]

15. Sytar, O.; Hemmerich, I.; Zivcak, M.; Rauh, C.; Brestic, M. Comparative analysis of bioactive phenolic compounds composition from 26 medicinal plants. Saudi J. Biol. Sci. 2018, 25, 631-641. [CrossRef] [PubMed]

16. Preethia, K.C.; Kuttanb, G.; Kuttan, R. Anti-inflammatory activity of flower extract of Calendula officinalis Linn. and its possible mechanism of action. Indian J. Exp. Biol. 2009, 47, 113-120.

17. Fronza, M.; Heinzmann, B.; Hamburger, M.; Laufer, S.; Merfort, I. Determination of the wound healing effect of Calendula extracts using the scratch assay with 3 T3 fibroblasts. J. Ethnopharmacol. 2009, 126, 463-467. [CrossRef]

18. Muley, B.; Khadabadi, S.; Banarase, N. Phytochemical Constituents and Pharmacological Activities of Calendula officinalis Linn (Asteraceae): A Review. Trop. J. Pharm. Res. 2009, 8, 455-465. [CrossRef]

19. Mohammad, S.M.; Kashani, H.H. Pot marigold (Calendula officinalis) medicinal usage and cultivation. Sci. Res. Essays 2012, 7, 1468-1472.

20. Parente, L.M.L.; Lino Júnior, R.D.S.; Tresvenzol, L.M.F.; Vinaud, M.C.; De Paula, J.R.; Paulo, N.M. Wound healing and anti-inflammatory effect in animal models of calendula officinalis L. growing in Brazil. Evidence-based Complement. Altern. Med. 2012, 2012,1-7. [CrossRef]

21. Miguel, M.; Barros, L.; Pereira, C.; Calhelha, R.C.; Garcia, P.A.; Castro, M.Á.; Santos-Buelga, C.; Ferreira, I.C.F.R. Chemical characterization and bioactive properties of two aromatic plants: Calendula officinalis L. (flowers) and Mentha cervina L. (leaves). Food Funct. 2016, 7, 2223-2232. [CrossRef] [PubMed]

22. Stratil, P.; Klejdus, B.; Kubáň, V. Determination of total content of phenolic compounds and their antioxidant activity in vegetables - Evaluation of spectrophotometric methods. J. Agric. Food Chem. 2006, 54, 607-616. [CrossRef] [PubMed]

23. Wong, C.C.; Li, H.B.; Cheng, K.W.; Chen, F. A systematic survey of antioxidant activity of 30 Chinese medicinal plants using the ferric reducing antioxidant power assay. Food Chem. 2006, 97, 705-711. [CrossRef]

24. Choi, Y.; Jeong, H.S.; Lee, J. Antioxidant activity of methanolic extracts from some grains consumed in Korea. Food Chem. 2007, 103, 130-138. [CrossRef]

25. Falleh, H.; Ksouri, R.; Oueslati, S.; Guyot, S.; Magné, C.; Abdelly, C. Interspecific variability of antioxidant activities and phenolic composition in Mesembryanthemum genus. Food Chem. Toxicol. 2009, 47, 2308-2313.

26. Odabasoglu, F.; Aslan, A.; Cakir, A.; Suleyman, H.; Karagoz, Y.; Bayir, Y.; Halici, M. Antioxidant activity, reducing power and total phenolic content of some lichen species. Fitoterapia 2005, 76, 216-219. [CrossRef] [PubMed]

27. Qasim, M.; Abideen, Z.; Adnan, M.Y.; Gulzar, S.; Gul, B.; Rasheed, M.; Khan, M.A. Antioxidant properties, phenolic composition, bioactive compounds and nutritive value of medicinal halophytes commonly used as herbal teas. South African J. Bot. 2017, 110, 240-250. [CrossRef]

28. Lee, J.; Koo, N.; Min, D.B. Reactive Oxygen Species, Aging, and Antioxidative Nutraceuticals. Compr. Rev. Food Sci. Food Saf. 2004, 3, 21-33. [CrossRef]

29. Kranner, I.; Minibayeva, F.V.; Beckett, R.P.; Seal, C.E. What is stress? Concepts, definitions and applications in seed science. New Phytol. 2010, 188, 655-673. [CrossRef] 
30. Prinsloo, G.; Nogemane, N. The effects of season and water availability on chemical composition, secondary metabolites and biological activity in plants. Phytochem. Rev. 2018, 17, 889-902. [CrossRef]

31. Fonseca, Y.M.; Catini, C.D.; Vicentini, F.T.M.C.; Nomizo, A.; Gerlach, R.F.; Fonseca, M.J.V. Protective effect of Calendula officinalis extract against UVB-induced oxidative stress in skin: Evaluation of reduced glutathione levels and matrix metalloproteinase secretion. J. Ethnopharmacol. 2010, 127, 596-601. [CrossRef] [PubMed]

32. Franco, D.; Sineiro, J.; Rubilar, M.; Sánchez, M.; Jerez, M.; Pinelo, M.; Costoya, N.; Núñez, M.J. Polyphenols from plant materials: Extraction and antioxidant power. Electron. J. Environ. Agric. Food Chem. 2008, 7, 3210-3216.

33. Herrero, M.; Cifuentes, A.; Ibañez, E. Sub- and supercritical fluid extraction of functional ingredients from different natural sources: Plants, food-by-products, algae and microalgae: A review. Food Chem. 2006, 98, 136-148. [CrossRef]

34. Castro-Vargas, H.I.; Rodríguez-Varela, L.I.; Ferreira, S.R.S.; Parada-Alfonso, F. Extraction of phenolic fraction from guava seeds (Psidium guajava L.) using supercritical carbon dioxide and co-solvents. J. Supercrit. Fluids 2010, 51, 319-324. [CrossRef]

35. Trabelsi, N.; Megdiche, W.; Ksouri, R.; Falleh, H.; Oueslati, S.; Soumaya, B.; Hajlaoui, H.; Abdelly, C. Solvent effects on phenolic contents and biological activities of the halophyte Limoniastrum monopetalum leaves. LWT - Food Sci. Technol. 2010, 43, 632-639. [CrossRef]

36. Gharbi, S.; Renda, G.; La Barbera, L.; Amri, M.; Messina, C.M.; Santulli, A. Tunisian tomato by-products, as a potential source of natural bioactive compounds. Nat. Prod. Res. 2017, 31, 626-631. [CrossRef]

37. Fish, W.W.; Perkins-Veazie, P.; Collins, J.K. A Quantitative Assay for Lycopene That Utilizes Reduced Volumes of Organic Solvents. J. Food Compos. Anal. 2002, 15, 309-317. [CrossRef]

38. Musa, K.H.; Abdullah, A.; Jusoh, K.; Subramaniam, V. Antioxidant Activity of Pink-Flesh Guava (Psidium guajava L.): Effect of Extraction Techniques and Solvents. Food Anal. Methods 2011, 4, 100-107. [CrossRef]

39. Manuguerra, S.; Caccamo, L.; Mancuso, M.; Arena, R.; Rappazzo, A.C.; Genovese, L.; Santulli, A.; Messina, C.M.; Maricchiolo, G. The antioxidant power of horseradish, Armoracia rusticana, underlies antimicrobial and antiradical effects, exerted in vitro. Nat. Prod. Res. 2018, 1-4. [CrossRef]

40. Oki, T.; Masuda, M.; Furuta, s.; Nishiba, y.; Terahara, N.; Suda, I. Involvement of Anthocyanins and other Phenolic Compounds in Radical-Scavenging Activity of Purple-Fleshed Sweet Potato Cultivars. J. Food Sci. 2002, 67, 1752-1756. [CrossRef]

41. Yeddes, N.; Chérif, J.; Guyot, S.; Sotin, H.; Ayadi, M. Comparative Study of Antioxidant Power, Polyphenols, Flavonoids and Betacyanins of the Peel and Pulp of Three Tunisian Opuntia Forms. Antioxidants 2013, 2, 37-51. [CrossRef] [PubMed]

42. Falleh, H.; Ksouri, R.; Medini, F.; Guyot, S.; Abdelly, C.; Magné, C. Antioxidant activity and phenolic composition of the medicinal and edible halophyte Mesembryanthemum edule L. Ind. Crops Prod. 2011, 34, 1066-1071. [CrossRef]

43. Messina, C.M.; Pizzo, F.; Santulli, A.; Bušelić, I.; Boban, M.; Orhanović, S.; Mladineo, I. Anisakis pegreffii (Nematoda: Anisakidae) products modulate oxidative stress and apoptosis-related biomarkers in human cell lines. Parasites and Vectors 2016, 9, 1-10. [CrossRef] [PubMed]

44. Abbes, M.; Baati, H.; Guermazi, S.; Messina, C.; Santulli, A.; Gharsallah, N.; Ammar, E. Biological properties of carotenoids extracted from Halobacterium halobium isolated from a Tunisian solar saltern. BMC Complement. Altern. Med. 2013, 13. [CrossRef]

45. Mosmann, T. Rapid colorimetric assay for cellular growth and survival: Application to proliferation and cytotoxicity assays. J. Immunol. Methods 1983, 65, 55-63. [CrossRef]

46. Ćetković, G.S.; Djilas, S.M.; Čanadanović-Brunet, J.M.; Tumbas, V.T. Antioxidant properties of marigold extracts. Food Res. Int. 2004, 37, 643-650. [CrossRef]

47. Efstratiou, E.; Hussain, A.I.; Nigam, P.S.; Moore, J.E.; Ayub, M.A.; Rao, J.R. Antimicrobial activity of Calendula officinalis petal extracts against fungi, as well as Gram-negative and Gram-positive clinical pathogens. Complement. Ther. Clin. Pract. 2012, 18, 173-176. [CrossRef]

48. Ercetin, T.; Senol, F.S.; Erdogan Orhan, I.; Toker, G. Comparative assessment of antioxidant and cholinesterase inhibitory properties of the marigold extracts from Calendula arvensis L. and Calendula officinalis L. Ind. Crops Prod. 2012, 36, 203-208. [CrossRef] 
49. Messina, C.; Renda, G.; Randazzo, M.; Laudicella, A.; Gharbi, S.; Pizzo, F.; Morghese, M.; Santulli, A. Extraction of bioactive compounds from shrimp waste. Bull. Inst. Natl. Sci. Technol. Mer Salammbô 2015 2015, 42, 27-29.

50. Oreopoulou, A.; Tsimogiannis, D.; Oreopoulou, V. Extraction of Polyphenols From Aromatic and Medicinal Plants: An Overview of the Methods and the Effect of Extraction Parameters. In Polyphenols in Plants; Elsevier Inc.: Amsterdam, The Netherlands, 2019; pp. 243-259. ISBN 9780128137680.

51. Bayar, N.; Kriaa, M.; Kammoun, R. Extraction and characterization of three polysaccharides extracted from Opuntia ficus indica cladodes. Int. J. Biol. Macromol. 2016, 92, 441-450. [CrossRef]

52. Matysik, G.; Wójciak-Kosior, M.; Paduch, R. The influence of Calendulae officinalis flos extracts on cell cultures, and the chromatographic analysis of extracts. J. Pharm. Biomed. Anal. 2005, 38, 285-292. [CrossRef] [PubMed]

53. Schlieve, C.R.; Lieven, C.J.; Levin, L.A. Biochemical activity of reactive oxygen species scavengers do not predict retinal ganglion cell survival. Investig. Ophthalmol. Vis. Sci. 2006, 47, 3878-3886. [CrossRef] [PubMed]

(C) 2019 by the authors. Licensee MDPI, Basel, Switzerland. This article is an open access article distributed under the terms and conditions of the Creative Commons Attribution (CC BY) license (http://creativecommons.org/licenses/by/4.0/). 